\title{
Party Gatekeepers' Support for Viable Female Candidacy in PR-List Systems
}

\author{
Dr Maarja Lühiste \\ Department of Politics and International Relations, University of Leicester \\ University Road, Leicester LE1 7RH, UK \\ m1325@leicester.ac.uk \\ $+447506461084$
}

\section{Abstract}

More women are elected in proportional compared to majority / plurality electoral systems.

However, the share of women among the elected representatives varies greatly between different types of PR systems, most notably between preferential and non-preferential PR-list systems. Considerable scholarly attention has been paid to how the voters with preference votes influence the election of women. But we have limited knowledge of how the party gatekeepers' behaviour influences the election of women in different types of PR-list systems. This paper aims to fill this gap by studying cross-nationally female candidates' partydetermined viability in different types of PR-list systems. The results suggest that women are placed lower in the electoral lists in ordered list preferential compared to closed list nonpreferential voting systems. The results also show that party gatekeepers respond to the overall levels of gender equality in the society, but only if the candidate selection within the party is centralised. 
It is difficult to overestimate the role candidate selection plays in determining the number of women in elected office. While increasing number of research has been dedicated to the impact political parties have on women's electoral representation (Caul 1999; Davidson-Schmich 2010; Kittilson 2006; Krook 2009; Krook 2010; Matland and Studlar 1996; Murray et al. 2012), the relationship between gender and candidate selection remains a relatively understudied area. Ashe and Stewart (2012) and Nieven (1998), however, provide empirical evidence that the majority of the variance in women's underrepresentation can be explained with demand side factors.

This research aims to take forward our knowledge on how the demand side influences women's underrepresentation by investigating at the individual level how party-gatekeepers rank order female candidates in electoral list in different types of party list proportional representation systems (PR-list systems). The list placement of candidates is an important stage in the overall electoral competition. In first-past-the-post (FPTP) systems a candidate's likelihood to be elected depends on the constituency in which she runs (Ryan et al. 2010). Similarly, in PR-list systems, candidate's likelihood to be elected depends largely on her electoral list placement. Past research concentrating on FPTP systems provide evidence that women are often overrepresented among hopeless candidates (i.e., candidates competing for marginal seats) (see for example, Deber 1982, Gertzog and Simard 1981; Ryan et al. 2010). However, little comparative attention has been paid to women's likelihood of viable candidacy in different types of PR-list systems.

This paper sets out to investigate what determines how political parties - the gateway to political office - place women in the electoral lists in PR-list systems with and without preference voting option (ordered $v s$. closed list PR-list systems). Most importantly, I concentrate on how varying combinations of parties' internal candidate selection procedures and certain electoral rules affect party-gatekeepers' choices. Past research suggests that 'with different electoral systems we could, and probably would, see different kinds of candidates' 
(Hazan and Voerman 2006: 148). In other words, party gatekeepers, presented with varying electoral rules, compose the party lists differently.

I study this question in the context of the 2009 European Parliamentary (EP) elections. The EP elections provide an excellent testing ground for this research as twenty out of the twenty-seven member states employ either closed or ordered list PR-list voting system. Also, these are the only PR-list elections for which there is a comprehensive cross-national candidate survey data set available - the 2009 European Election Study (EES) Candidate Survey. The results of the analysis suggest that viable candidate selection differs across institutional and contextual settings: women are placed lower in the electoral lists in ordered list systems compared to closed list systems. The results also show that party gatekeepers respond to the overall levels of gender equality in the society, with women enjoying more viable list rankings in more gender equal societies; but only if the candidate selection within the party is centralised.

\section{Party-determined viable candidacy in PR list systems}

While candidate selection is referred to as 'the secret garden of politics' (Gallagher and Marsh 1988), it is one of the most important stages in the electoral process. Candidate selection not only determines the choices given to voters - which influences how the vote choice is perceived and made - but it also determines the composition of the parties in the legislature (Crotty 1968; Hazan and Voerman 2006).

Past research identifies four groups of variables affecting aspirants' chances in the candidate selection process: (i) individual characteristics summarising the traits the selectors are looking for in a candidate; (ii) party rules concerning who and at what level can elect / appoint candidates; (iii) institutional settings conditioning the selectors' choices; and (iv) wider contextual settings and selectors' perception of voter preferences (Gallagher and Marsh 1988; Hazan and Voerman 2006; Katz 1980; Norris 1997). This paper proceeds by covering the main 
expectations with regards to how these traditional predictors of candidate selection affect women's likelihood of viable candidacy. While the classic works on candidate selection examine the likelihood of aspirants to become a candidate, in this research I study what distinguishes a viable candidate from all other candidates. Therefore, the initial pool of cases from which viable candidates are 'selected' is not all aspirants but all candidates.

\section{Individual characteristics that the selectors are looking for}

While most political parties do not have a set of formal requirements prospective candidates need to meet, party gatekeepers value candidates with traits such as incumbency, political experience, and party loyalty (Gallagher and Marsh 1988; Shugart et al. 2005). Gallagher and Marsh (1988) also emphasise the demographic characteristics of potential candidates, but note that parties often use the lower, electorally hopeless places on the list for producing a balanced ticket. Therefore, while being a woman may increase an aspirant's chance of being selected as a candidate it may decrease her chances of being granted with a viable candidacy. Past research concentrating on the US House Elections and British General Elections provide evidence that women are overrepresented among hopeless candidates (see for example, Deber 1982; Gertzog and Simard 1981; Ryan et al. 2010).

In terms of other individual characteristics, past research considers incumbency and political experience as key traits that increase an aspirant's chances of being selected as a candidate (Gallagher and Marsh 1998; Norris 1997; Shugart et al. 2005; Valdini 2012). The level of individual candidate's political aspirations could affect her viability, too. It is likely that candidates who express high levels of political ambition may fight for their electoral list position more and in turn be granted with a more viable list position than candidates who show little or no apparent motivation to become an MEP.

Based on the elaborations above, I hypothesise that at the individual level, (H1) female candidates, (H2) candidates with no or limited political experience, and (H3) candidates who 
show little or no apparent motivation to become an MEP are likely to be underrepresented among viable candidates in PR list systems.

\section{Parties' candidate selection rules}

Different parties apply varying candidate selection rules, which are likely to affect the outcome of candidate selection, too. Rahat and Hazan (2001) distinguish four dimensions of candidate selection: (i) candidacy (who can run), (ii) the inclusiveness of the selectorate (who can vote / choose), (iii) decentralisation (whether candidates are selected at local, regional, or national level), and (iv) voting vs. appointment (whether all candidates are selected by a voting procedure). Since there is little variation across the EU countries in terms of the first and the fourth dimension, I will concentrate on the inclusiveness and decentralisation variables only.

Current research offers a somewhat unclear picture of the relationship between centralisation of candidate selection and women's representation. On one hand, the literature on political parties expects decentralised parties to be more open to new ideas (Kitschelt 1994). As women candidates remain relatively 'novel' in most countries, one could take Kitschelt's (1994) argument further and claim that a more decentralised party could thus select more women in the party lists.

Matland and Studlar (1996), however, offer a counter-argument: party-gatekeepers in a more centralised party can be held more directly accountable as local party leaders cannot point fingers at one another and thus cannot escape the responsibility for their failure to promote women. In the case of centralised candidate selection different interest groups within the party, such as women's factions, are also likely to be more organised and thus stronger in pursuing support for specific candidates. More recent literature further supports this counter-argument (Caul 1999; Kittilson 2006). Kittilson (2006: 34) suggests, for example, that 'in a centralised party, the leadership has the ability to make and enforce the new rules' and thereby advance the position of women in the party list. 
Hence, a number of politics and gender scholars (Caul 1999; Matland and Studlar 1996; Kittilson 2006) agree that a more centrally organised party is more likely to respond to women's demands for a more equitable representation. Derived from that, one could assume that more centralised candidate selection procedures, too, would increase women's chances for viable candidacy, because it is likely that there is a rather strong correlation between overall party centralisation and the centralisation of candidate selection. Past research, however, shows that decentralised candidate nomination slightly increases the levels of women's political representation (Kittilson 2006). However, that finding holds in an analysis, which also shows that centralised party organisation is a strong positive predictor of women's representation. Kittilson (2006: 127) explains these rather counterintuitive findings with a claim that 'in a centralised party, national authorities have the power to persuade local constituencies to implement standard policies to promote women'. Kittilson (2006) thus argues that centralised party organisation is an important precondition for women to enjoy higher levels of representation in parties where candidates are nominated locally. As the level of candidate nomination is one of the weaker indicators and overall party centralisation is one of the stronger indicators in Kittilson's (2006) analysis, decentralised candidate selection on its own is unlikely to increase women's chances for viable candidacy.

Greater inclusiveness of the selectorate is likely to affect women's candidacy, too. The literature on preference voting argues that one of the reasons why less women are elected in preference voting systems compared to closed list voting systems is due to the fact that party elites may 'understand' better than the wider masses the necessity of women's representation (Matland 2005). Hence, women should be placed in more viable list positions in parties with less inclusive selectorates. Moreover, Hazan and Rahat (2006) claim that more inclusive selectorates are less successful in balancing the composition of candidate list because candidates from the dominant group can win most of the safe positions on the list. 
Another party level variable that is likely to affect women's chances for viable candidacy is party ideology. The main assumption is that left-wing parties are more likely to support women's candidacies because they promote more egalitarian ideologies than rightwing parties (Duverger 1955). Most gender and politics scholars find empirical evidence of the positive relationship between the strength of left-wing ideology and women's descriptive representation (Caul 1999; Norris and Franklin 1997; Reynolds 1999).

Based on the elaborations above, I hypothesise that at the party level, (H4) parties that select candidates centrally (on a national level) and are thus organised more centrally, (H5) parties where the selectorate is more exclusive, and (H6) parties representing left-wing ideology nominate more women as viable candidates in their electoral lists.

\section{The structure of opportunities: institutional setting}

As noted above, parties are not entirely independent in their decision of 'selecting' (viable) candidates. The electoral rules condition and constrain the parties' menu of choices concerning candidate selection (Hazan and Voerman 2006). The central institutional variable of interest in this research is the specific voting system used in PR list electoral systems.

This paper examines the effect of PR-list electoral systems on women's viable candidacy based on ballot (the extent of party control over who is elected) and district magnitude (the number of seats per electoral district). Past literature distinguishes three types of ballot structure: (i) parties present a ballot that cannot be altered by voters; (ii) parties present a ballot that can be altered by voters; and (iii) parties have no control over the ballot (Carey and Shugart 1995; Renwick and Pilet 2011). As this paper concentrates on how party gatekeepers' influence individual candidates' viability, I examine only those PR-list systems that fall in the former two categories - closed list and ordered list systems - in which partygatekeepers have some actual power to influence individual candidate's electoral chances ${ }^{\mathrm{i}}$.

We could assume that women's likelihood for viable candidacy varies in different 
voting systems because party gatekeepers are likely to balance their ticket differently in these two different types of systems. It is likely that female candidates are faced with different chances for viable candidacy in a situation (i) in which only parties determine individual candidate's viability (closed lists), or (ii) where parties determine individual candidate's viability but voters can disturb it with preference votes (ordered lists) ${ }^{\mathrm{ii}}$.

Closed party lists put the responsibility on the political party to balance the representation of different demographics, interests, and groups among candidates. In such a system, different factions in the party, e.g. women's faction, are likely to put pressure on party gatekeepers not only to include enough women in electoral lists but to ensure women have viable list positions. As list position determines everything in closed lists systems, it also means that these different factions within parties can hold party gatekeepers responsible for their dismal commitment to fielding female candidates.

In ordered list systems, on the other hand, parties affect individual candidate's electoral chances with the initial list placement but they cannot be held solely responsible for impeding women's representation, as voters have the opportunity to change the list order with preference votes. This means that party gatekeepers may have less incentive to include more women in viable list positions because the chain of responsibility is weaker. Moreover, in systems where preference voting is available, party gatekeepers may suggest that women could 'make up' their potentially weaker list ranking with preference votes. Past research suggests that any personal characteristic that marks a candidate as distinct from the others in her party, and that allows constituents to identify with candidate, can be seen as a potential advantage in gaining preference votes (Carey and Shugart 1995; Katz 1980; Shugart et al. 2005). In other words, the potential advantage of being a woman in gaining preference votes could be used by party gatekeepers as an excuse to rank women lower in the list than men.

Besides electoral rules, parties' menu of choices in terms of candidate selection is also conditioned by whether the party has adopted or the state has imposed candidate gender quotas. 
While candidate gender quotas operate primarily at the moment of candidate selection, Krook and Norris (2014) argue that elites may still believe that women are not viable candidates. Hence, in some cases the quota rules increase the share of women among candidates but not among viable candidates. Previous literature also suggest that quota effectiveness depends on how they interact with other elements of the political environment (Jones 2009; Krook 2009, Krook and Norris 2014). Jones (2009) and Tripp and Kang (2008) find, for example, that quotas with placement mandates are the most effective, while general legislative quotas appear the least efficient measure to increase women's descriptive representation. While both Jones (2009) and Tripp and Kang's (2008) study uses women's descriptive representation as dependent variable, I expect candidate quotas to influence viable female candidacy the same way.

I therefore hypothesise that at the political system level, (H7) women have a lower likelihood of being placed on a viable list position in ordered list preferential than in closed list non-preferential voting system, and that (H8) candidate gender quotas have a positive effect on women candidates' chances to be granted with viable candidacy only if the quota rule includes a placement mandate measure.

The structure of opportunities: contextual setting

Besides institutional rules, the overall gender norms and equality in the society are likely to affect party gatekeepers' decisions when ranking candidates in the electoral lists. In a country where overall levels of gender equality are high, there are not only more potentially viable female candidates but also the expectations within the party and in the society about women's position in the party list are likely to differ from a member state where gender inequality is prevalent and more accepted. Overall gender equality is reported to be both a strong positive predictor of women's candidacy (Valdini 2012) and descriptive representation (Jones 2009; Matland 2005; Schwindt-Bayer and Mishler 2005; Tripp and Kang 2008). Besides direct effect, 
I expect overall gender equality to condition the effect of other institutional and party level variables, too. Valdini (2012) argues, for example, that the selectorate has a strong incentive to be attentive to the prevalence of traditional or liberal gender norms in the society and thus balance the ticket accordingly. (H9) Therefore, I expect women to have a higher likelihood of being positioned in the electoral lists as viable candidates in more gender equal societies.

\section{European Parliament elections}

This research investigates the hypothesis stated above in the context of the 2009 EP elections. The literature on EP elections frequently classifies them as second-order elections that are less important than national elections, as there is no government formation (Hix and Marsh 2011; Reif and Schmitt 1980). Yet, often the same candidates and parties compete in both first- and second-order elections (Franklin 2006; Reif and Schmitt 1980). However, past research shows that women have better access to second-order elected offices than to national legislative seats (Darcy et al. 1994; Ford and Dolan 1999; Kantola 2009; Matland and Studlar 1998).

The fact that the European Parliament elections are second-order elections could pose a potential problem for the research. The results from the EP elections could prove 'too positive' in the sense that we may overestimate women's chances for viable candidacy. Due to this reason, I acknowledge the fact that the results of the following analysis have some limitations. While second order elections matter less than first order elections, it would also be unreasonable not to exploit the neat data the European Election Study offers to learn more about women's electoral representation. Also, like other second order offices, European Parliament may serve as a point of departure to many women on their pursuit for national elected office. Past literature shows that over half of the MEPs have held no previous elected positions, not even local government offices, and nearly one fifth of the MEPs continue to national parliaments (Scarrow1997). Therefore, studying women's chances at the European 
Parliament elections should give us some cues about these same women's chances in future national elections, too.

Indeed, the European Parliamentary elections are 'a fascinating research site' because it 'presents the opportunity to craft powerful research designs incorporating an unusual, indeed probably unique degree of controlled comparison: between members [candidates] of the same political institution chosen under a range of different electoral arrangements' (Farrell and Scully 2010: 36). I consider the European elections the most suitable testing ground for the main hypotheses of the paper primarily because all member states have to employ proportional electoral systems, while they are free to choose the level of openness of the ballot structure. Besides controlling for proportional electoral system, I also control for the type of institution representatives are elected to and the time of the election.

\section{Data, method, and measurement}

This paper relies on the 2009 European Election Study (EES) Candidate Survey and general institutional and contextual data. The 2009 EES Candidate Study offers a unique data set to examine candidates at the European Elections. In total, more than 6500 candidates were contacted, ranging from 29 candidates in Cyprus to 881 in the United Kingdom (Giebler et al. 2010). The mean response rate for all countries combined is $22 \%{ }^{\mathrm{iii}}$ (Giebler and Wessels 2010). There is a significant variation of response rate by party and country (Giebler and Wessels 2010). In order to address the dissimilarities in response rates, survey weights are used in the analysis. This paper utilises a combined weight for party affiliation and the number of MEPs per country. Fortunately, there seem to be no systematic patterns of non-response in terms of gender, chance to get elected or in regard to actual electoral success (Giebler et al. 2010). Hence, there is no significant response bias regarding the central variables of interest.

Since this paper focuses on women candidates' viability in ordered and closed list voting systems only, I utilise responses to the EES Candidate Survey from the 20 EU member 
states $^{\text {iv }}$ that employ the aforementioned ballot structure. The final sample consists of 1020 respondents, $34 \%$ of whom are women.

\section{Dependent variable and method}

The dependent variable is candidate's party-determined viability. I use a measure developed by Giebler and Wessels (2010). The categorisation of the overall viability variable is based on the candidate's list position in relation to the potential number of seats won by her party (Hix et al. 2009). I use this variable instead of original list ranking because it takes into account party's overall viability. Since different parties expect to win varying numbers of elected seats, list ranking alone does not fully explain individual candidate's viability. In order to incorporate uncertainty in the measure, the standard deviation of discrepancy between the predictions and the seats that were actually won was calculated for each country. As a result, candidates with a list position below the predicted seats minus one standard deviation were classified as 'safe' candidates. Candidates with a list position above the predicted seats plus one standard deviation were classified as 'unpromising' candidates, and all other candidates were classified as 'doubtful' (Giebler et al. 2010a). 5.7\% of the respondents are coded as 'safe', $12.7 \%$ as 'doubtful', and $81.6 \%$ as 'unpromising' candidates.

The party-determined candidate viability measure is by its nature an ordinal variable, because a natural ordering exists for these categories ('unpromising' is worse than 'doubtful'; 'doubtful' is worse than 'safe'). As the data used for the analysis do not meet parallel regression assumption, I employ multinominal logistic regression models (MNLM). MNLM is considered as a reasonable alternative to ordered logistic regression models when the parallel regression assumption is not met (Long 1997; Long and Freese 2006). 


\section{Operationalisation of independent variables}

This paper utilises the 2009 EES Candidate Survey responses for measuring all individual level variables. Survey respondents were asked whether they are or have ever been a member of the following bodies: local representative body, regional representative body, national representative body, member of the EP, member of local government, member of regional government, and/or member of national government. The political experience index, used in this study, is measured as the proportion of memberships in relation to the total number of items (for more information, see Giebler et al. 2010). The respondents were also asked which of the aforementioned bodies they 'would like to be ten years from now'. Each candidate was asked to choose as many options as appropriate. Political ambition is measured based on this survey question. Ambitions for positions in the EP are coded as ' 1 ', all others coded as ' 0 '.

I use the 2009 EES Candidate Survey question 'on which level were you nominated as an official candidate for the EP election?' as an indicator of the centralisation of candidate selection procedures. The values of the variable used increase from de-centralised to centralised candidate selection: local level (1), regional level (2), and national level (3). More than half of the respondents (57\%) are nominated at the national level. I also rely on candidates' survey responses to measure the inclusiveness of the selectorate. I use the original categories of the 2009 EES Candidate Survey, ranging from exclusive to inclusive candidate selectorate: the executive board of your party (1), appointed party members (2), elected party members (delegates) (3), all party members (4), and voters (5). Most often candidates are officially nominated by the executive board of their party (43\%) or by elected party members (delegates) (22\%). The final party level variable, whether the candidate's party represents Left-wing / liberal / ecological ideology or not, is measured as a dichotomous variable. If the candidate's national party has affiliation with the Social Democrats, Liberals and Liberal Democrats, 
Greens and Regionalists, or Communists, Democratic Socialists and the far Left European Parliamentary party groups, the variable is coded as ' 1 ', otherwise ' 0 '.

For the analysis, I use a dichotomous variable to distinguish between ordered list and closed list voting systems, where closed list voting system is the baseline category. Member states are classified similarly to Farrell and Scully (2005), with the exception of Poland, which according to its Electoral Law is an open list, not a closed list system (Giebler 2012; Kotnarowski 2012). Austria, Belgium, Bulgaria, Cyprus, Czech Republic, Latvia, Lithuania, the Netherlands, Slovakia, Slovenia, and Sweden are coded as ordered list voting systems. Estonia, France, Germany, Greece, Hungary, Portugal, Romania, Spain, and the United Kingdom (excl. the Northern Ireland constituency) are coded as closed list voting systems. District magnitude is coded as the number of MEP seats the constituency in which the candidate runs has.

For measuring overall gender equality in society, I calculated a gender equality index (GEI) based on a modified EU Gender Equality Index (Platenga et al. 2009). The Gender Equality Index used in this research includes four major areas of life where equality between men and women varies across Europe: equal share of employment; equal share of money; equal share of (decision-making) power; and equal share of time. The exact measurement of the gender equality index is explained in Appendix 1.

Regarding candidate gender quotas, I distinguish between cases in which: (i) no quota rule is applied, (ii) simple quotas without placement mandate rule are applied; and (iii) quotas with placement mandate rule are applied. The Quota Project's database is used for the categorisation. The quota measures are dichotomous variables, where value ' 0 ' indicates no such quota rule and value ' 1 ' indicates this specific quota rule. 


\section{Results and discussion}

Table 1 summarises the results of the overall model, which includes all candidates. The results show that women are not less (or more) likely than men to be viable candidates; the results also hold if a binary model with candidate sex as the only explanatory variable is estimated.

\section{Table 1 here}

However, in order to understand whether and how electoral rules affect women candidates' chances for party determined viable candidacy, I run separate models for male and female candidates and compare the differences of the coefficients with Wald tests ${ }^{\mathrm{v}}$. This approach is applied, instead of running a model with gender interaction terms, because I expect different variances for the two groups.

Table 2 explains both female and male candidates' likelihood of being placed by party gatekeepers as viable candidates. To recall, candidate viability is measured with a 3-category variable, where 'safe' indicates highly viable list position, 'doubtful' indicates semi-viable list position, and 'unpromising' indicates a list position from which it is highly unlikely to get elected. The left-hand section of Table 2 summarises how the independent variables influence the likelihood of being positioned in the party lists as a doubtful candidate as opposed to an unpromising candidate. A negative coefficient indicates that the independent variable decreases the candidate's chances of being a doubtful candidate as opposed to unpromising and vice versa. The right-hand section of Table 2 shows how the independent variables affect the likelihood of being positioned in the party lists as a safe as opposed to a doubtful candidate.

Most importantly, the results in Table 2 demonstrate that female candidates' likelihood of being placed in the party lists as viable candidates is considerably more dependent on the institutional and contextual setting in which they run than male candidates' likelihood of viability. For men, the single most important (and consistently statistically significant) variable explaining their chances for being ranked high on parties' electoral lists is their personal political experience. For women, political experience fails to reach traditional levels of 
significance $^{\mathrm{vi}}$. Berch (2004) shows similar results: female incumbents face more challenges in being re-elected than male incumbents do in US House Elections.

Most notably, Table 2 shows the strong effect of overall gender equality in the society on women candidates' chances to be granted with a highly viable list position. The effect of preferential voting systems is somewhat less straight-forward. Preferential voting system appears to increase women's chances of not being an unpromising but a somewhat viable doubtful candidate. However, the positive effect of preferential voting system ends with semiviable doubtful candidacy, as women have a much higher likelihood of being granted a highly viable safe candidacy in non-preferential closed list voting systems. I assume that it is the safe candidacy that matters the most in the electoral competition. Therefore, the fact that in closed list systems women are ranked relatively higher in the electoral lists than they are in ordered list systems, suggest that women also have higher chances for election in closed list systems.

Alternatively, one could argue that in an ordered list system, a moderately viable list position (doubtful candidacy) is enough as in this system candidates' likelihood of getting elected does not only depend on their list position but also on how many preference votes they gain. Hence, it is still possible to get elected, even if the party places the candidate on semiviable doubtful position, rather than on highly viable safe position. However, this means that in order for women to have the same likelihood as men for getting elected, female candidates in doubtful list positions need to collect much more preference votes than the male candidates in safe list positions. Research on preferential voting does not show that women are consistently more (or less) likely to gain preference votes than men (Matland 2005; Sanbonmatsu 2002; Smith and Fox 2001). Therefore, less viable party-determined electoral list placement is likely to negatively influence these women's overall electoral chances and thus explain why past literature finds that women in preferential voting system have lower levels of descriptive representation than women in non-preferential voting systems (Caul 1999; Hogan 2001; Norris 
1996; Norris and Franklin 1997; Paxton and Kunovich 2003; Reynolds 1999; Schwindt-Bayer and Mishler 2005).

Besides the electoral arrangements, women candidates' chances for viable candidacy are also influenced by the rules in the party office and party ideology. Unlike male candidates, female candidates' likelihood of viable candidacy is affected by the level of candidate selection. In line with the expectations, women candidates are more likely to be hopeless candidates and less likely to be highly viable safe candidates if they are selected at the local/regional level as opposed to the national level. However, whether candidates are officially nominated by a small group of party executive members or by a more inclusive selection body does not statistically significantly affect women candidates' chances for being placed in winnable list positions. Caul (1999) and Norris (2006) argue that the move to more inclusive selectorates in Western Europe occurred at the same time as an increase in the use of various correction mechanisms to assure the representation of women. Therefore, the empirical findings of this paper seem to suggest that parties may indeed restrict the choices of their more inclusive selectorates with these 'correction mechanisms' in order to facilitate the election of women. Finally, the results also show that Left-wing parties continue to support viable female candidacy more than Rightwing parties.

In line with the expectation, only quotas with placement mandate increase women's likelihood of being granted with viable candidacy, while quota rules without a placement mandate regulation remain ineffective in increasing women candidates' chances for viable candidacy. However, it is important to note that quotas with placement mandate rules affect women's chances for highly viable candidacy only, and not for doubtful candidacy. This may be influenced by the specific quota rules applied. For example, in Belgium only two top candidates of the party list cannot be of the same gender, while there is no alternation required throughout the list. 
While the analysis suggests that both individual and contextual level variables affect women candidates' likelihood for viable candidacy differently than men's, it is difficult to explain why this is the case. The fact that men are, in general politically more experienced than women, could partly explain why political experience explains men's chances for viable candidacy but not women's. Also, the same fact that women are in general under-represented in politics is likely to explain why context matters more for women's individual chances of being placed in a viable list position than it does for men's. Female candidates could be seen as the 'political underdogs' who need a more favourable context to guarantee a viable list position. Male candidates, due to the fact that they are the more common political actors, are less sensitive to the context in which they run.

The results discussed above illustrate how certain characteristics of the electoral system and the overall context can have a positive or negative impact on women's likelihood of being positioned by party gatekeepers as viable candidates. However, the central variables of interest, the voting system, the centralisation of candidate selection, and the overall gender equality in the society do not always go hand-in-hand. To estimate the full impact of the voting system, overall gender equality, and candidate nomination procedures within parties, I report predicted probabilities of party-determined viable candidacy for women across a range of situations ${ }^{\mathrm{vii}}$.

Figure 1 depicts the difference of the effect of overall gender equality and candidate selection procedures within parties across ordered list and closed list voting systems. The top section of Figure 1 shows the strong positive effect overall gender equality has on women candidates' chances to be granted with a highly viable (safe) candidacy in closed list systems. However, the overall levels of gender equality affect little women's probability of viable candidacy in preferential ordered list systems. These results indicate that closed list voting rules may not increase women's chances for party-determined viable candidacy in countries where women are relatively unequal to men. However, in a society with above average levels 
of gender equality, women appear to be considerably more likely to be viable candidates when a non-preferential voting system is employed.

Figure 1 here

Continuing with the electoral system effects, the bottom section of Figure 1 depicts that women have close to zero probability of being positioned by party gatekeepers as a doubtful or safe candidate in both ordered and closed list systems if the candidate selection is carried out at the local level. However, there are differences in women's probabilities for party-determined viable candidacy across voting systems once the decision of candidate selection is made either at regional or national level. Most notably, more centralised candidate selection procedures increase women's probability of viable candidacy in both ordered and closed list systems. However, while in preferential ordered list systems more centralised candidate selection increases women's chances of doubtful candidacy, in closed list preferential voting systems it increases women's chances of safe candidacy. Therefore, the combination of centralised candidate selection with closed list ballot structure appears the most likely context in which women can expect to be granted a highly viable candidacy.

Figure 2 depicts party gatekeepers response to overall gender equality dependent on candidate selection procedures and party ideology. The top section of Figure 2 illustrates that different candidate selection procedures within political parties also condition the effect of overall gender equality on women candidates' party-determined viability. While overall gender equality does not influence women candidates' likelihood of being granted with a highly viable (safe) candidacy in cases where candidates are nominated in local party offices, gender equality has a strong effect on women's party-determined viability in cases where candidates are nominated at the national level. The effect of gender equality on viable candidacy also varies by party ideology. The bottom section of Figure 2 shows that women in both right- and leftwing parties enjoy a higher probability of highly viable safe candidacy in relatively gender equal societies only. These findings are interesting because they indicate a mechanism of how 
overall levels of gender equality influence women's likelihood of being placed in winnable seats.

Figure 2 here

One of the arguments of how overall levels of gender equality affect women's electoral chances is that in more gender equal societies there is a greater supply of prospective female candidates. The fact that both left- and right-wing parties place women in highly viable safe list position in highly gender equal societies only could indicate that in more gender equal societies there is a greater supply of potentially highly viable candidates. However, the supply side argument does not explain the results depicted in the top section of Figure 2, which rather point to party gatekeepers. There are stark differences in the likelihood of women from moderately or highly gender equal societies to be placed at highly viable (safe) seats dependent on the centralisation of candidate nomination. I consider it unlikely that in relatively gender equal societies the supply of suitable female candidates for viable list positions varies substantively dependent on whether the party selects its candidates at the local or at the national level. Rather it appears that party gatekeepers seem to respond more to the overall context of gender equality, thus to the perceived demand, if candidate selection is more centralised.

Valdini (2012) argues that the selectorate has a strong incentive to be attentive to the prevalence of gender equality in the society and thus balance the ticket accordingly. These results show a more nuanced finding: whether or not party gatekeepers are attentive to the overall gender ideology in the society depends on the level at which party gatekeepers select candidates.

\section{Final comments}

The data from the 2009 European Parliament elections show that while women have no lower likelihood of party-determined viable candidacy than men, the institutional setting and overall context in which they run affects female candidates' chances for viability more than male 
candidates' chances. Context matters for female candidates. This is both bad news and good news. Certain contextual predictors, such as overall gender equality in the society, are not easily changed. However, institutional rules, such as the type of voting systems used and the level at which candidate selection takes place in political parties, are not only theoretically changeable but history shows that these features of electoral systems and party rules are indeed occasionally changed. Therefore, change in electoral rules towards closed list voting (as opposed to ordered list voting) and towards more centralised party selection procedures are likely to increase women's chances of party-determined viable candidacy, which is likely in turn to increase their chances of being elected.

The findings of this paper thus show the general trend towards more 'open' electoral systems (Renwick and Pilet 2011) and more decentralised and inclusive candidate selection procedures (Hazan and Rahat 2006) in a different light. While this change in electoral and internal party rules is usually presented as a move towards a more democratic institutional setting, this paper shows that these current changes may have a negative effect on women's descriptive representation.

The results of the analysis also suggests that party gatekeepers respond to the overall levels of gender equality and place women in more viable list positions in more gender equal societies. Moreover, the effect is the strongest in closed list voting systems and within parties where candidate selection is centralised. I assume that this is the case because in a more centralised party organisation it is likely to be easier for the women's factions in the party (or other interest groups) to hold the party gatekeepers responsible for their illicit decisions when fielding women candidates.

The paper offers interesting findings with regards to candidate gender quotas. While I expected candidate gender quotas without a placement mandate rule to remain ineffective, quotas with placement mandate also have a limited effect. In countries and parties where placement mandate rule is used, women have a higher likelihood of highly viably candidacy 
but not of moderately viable candidacy. I assume that this is due to the fact that some parties, such as the Moderate Party in Sweden, and countries, such as Belgium and Slovenia, apply the placement mandate rule in the top part of the list only.

In conclusion, this research provides important information with regards to partydetermined viable candidacy. These findings are likely to help us explain certain mechanisms of the election of women in general, too. For example, the fact that party gatekeepers place women on moderately viable, rather than highly viable, list positions in preferential ordered list systems and on highly viable list positions in closed list systems may explain why we witness fewer women in the legislatures in preferential than in non-preferential PR-list electoral systems. Future studies could put this claim to test and examine if and how the differences in women candidates' party-determined viability across varying institutional and contextual contexts affect women's chances of being elected. 
${ }^{\text {i } I ~ t h u s ~ e x c l u d e ~ c o u n t r i e s ~ t h a t ~ e m p l o y ~ S T V ~(I r e l a n d, ~ M a l t a, ~ a n d ~ N o r t h e r n ~ I r e l a n d ~ c o n s t i t u e n c y ~}$ of the UK) or open list (Finland, Denmark, Italy, Luxembourg, and Poland) proportional electoral systems for electing their representatives to the European Parliament, because in those systems party gatekeepers cannot directly affect the viability of individual candidates in the lists.

${ }^{\text {ii }}$ It is important to keep in mind the limitations of this overly simplified dichotomous measure. While closed list systems are rather homogenous, ordered list systems can vary with regard to the degree to which preference votes determine the electoral fate of candidates. Yet, limited information is available on more specific electoral rules certain countries apply for the European Parliament elections, and it would be disingenuous to create a possibly flawed measure.

iii The principal investigators of the 2009 EES Candidate Survey data also note that the response rates of the 2009 study are comparable to respective numbers of the study in 1994 undertaken by Thomassen, Katz, Norris, and Wessels (the over-all response rates are identical). Hence, they state that, 'In sum, the representativeness of the 2009 European Election Candidate Study seems acceptable in comparison to the 1994 study which produced highly enlightened insights into European political elites competing for seats in the European Parliament'. ${ }^{\text {iv }}$ As a result, observations from Denmark, Finland, Ireland, Italy, Malta, Luxembourg, Poland, and the Northern Ireland constituency of the United Kingdom are dropped from the sample. ' I use the 'suest' (seemingly unrelated estimation) command in Stata which combines the estimation results - parameter estimates and associated (co)variance matrices - stored under namelist into one parameter vector and simultaneous (co)variance matrix of the sandwich/robust type. Typical applications of 'suest' are tests for intra-model or cross-model hypotheses.

${ }^{\mathrm{vi}}$ I also estimated models in which I replaced the political experience variable with the incumbency variable. While the incumbency variable reached statistical significance also for women, the coefficient remained significantly larger for men. All other covariates showed no substantive differences whether I ran the model with the political experience or with the incumbency variable.

vii I utilise the 'prgen' command in Stata (Long and Freese 2006) to compute predicted outcomes as one independent variable changes over a specified range, holding other variables constant. I have plotted the new variables containing the predicted values in Figure 1 and Figure 2. 


\section{BIBLIOGRAPHY}

Ashe, Jeanette and Kennedy Stewart (2012) 'Legislative Recruitment: Using Diagnostic Testing to Explain Underrepresentation', Party Politics 18(5): 687-707.

Berch, Neil (2004) 'Women Incumbents, Elite Bias, and Voter Response in the 1996 and 1998 U.S. House Elections', Women \& Politics 26(1): 21-33.

Carey, John M. and Matthew S. Shugart (1995) 'Incentives to Cultivate a Personal Vote: A Rank Ordering of Electoral Formulas', Electoral Studies 14(4): 417-439.

Caul, Miki (1999) 'Women's Representation in Parliament: The Role of Political Parties', Party Politics 5(1): 79-98.

Crotty, William J. (1968) ‘The Party Organization and its Activities', in William Crotty (Ed.), Approaches to the Study of Party Organization. Boston, MA: Allyn \& Bacon.

Darcy, Robert, Susan Welch, and Janet Clark (1994) Women, Elections, and Representation, $2^{\text {nd }}$ ed. Lincoln: Nebraska University Press.

Davidson-Schmich, Louise K. (2010) 'Gender Quota Compliance and Contagion in the 2009 Bundestag Election', German Politics \& Society 28(3): 133-155.

Deber, Raisa B. (1982) “"The Fault, Dear Brutus”: Women as Congressional Candidates in Pennsylvania' Journal of Politics 44(4): 463-479).

Duverger, Michael. 1955. The Political Role of Women. Paris: UNESCO.

European Election Study (2010) Candidate Survey Data. Available at http://www.piredeu.eu. (Last accessed February 1, 2012).

Farrell, David M. and Roger Scully (2010) 'The European Parliament: One Parliament, Several Modes of Political Representation on the Ground?' Journal of European Public Policy 17(1): 36-54.

Ford, Lyanne and Kathleen Dolan (1999) 'Women State Legislators: Three Decades of Gains in Representation and Diversity', in Lois Duke Whitaker (Ed.), Women in Politics: Outsiders or Insiders?: A Collection of Readings. Upper Sadler River, NJ: Prentice Hall. 
Franklin, Mark (2006) 'European Elections and the European Voter', in Richardson, J. (Ed.), European Union: Power and Policy Making. $2^{\text {nd }}$ Edition. Oxon, UK: Routledge.

Gallagher, Michael, and Michael Marsh (1988) Candidate Selection in Comparative Perspective: The Secret Garden of Politics. London: Sage.

Gertzog, Irwin N. and M. Michele Simard (1981) 'Women and "Hopeless” Congressional Candidacies: Nomination Frequency, 1916-1978’ American Politics Quarterly 9(4): 449466.

Giebler, Heiko and Bernhard Wessels (2010) '2009 European Election Candidate Study Methodological Annex', Berlin: WZB, www.piredeu.eu (8 Aug 2011).

Giebler, Heiko, E. Haus, and Bernhard Wessels (2010) '2009 European Election Candidate Study - Codebook, Advance Release', WZB: Berlin, www.piredeu.eu (8 Aug 2011).

Giebler, Heiko (2012) Personal communication (e-mail). 28 March 2012.

Hazan, Reuven Y. and Gideon Rahat (2006) 'The Influence of Candidate Selection Methods on Legislatures and Legislators: Theoretical Propositions, Methodological Suggestions and Empirical Evidence', The Journal of Legislative Studies 12(3-4): 366-385.

Hazan, Reuven Y. and Gerrit Voerman (2006) 'Electoral Systems and Candidate Selection', Acta Politica 41(1): 146-162.

Hix, Simon and Michael Marsh (2011) 'Second-Order Effects Plus Pan-European Political Swings: An Analysis of European Parliament Elections Across Time', Electoral Studies 30(1): 4-15.

Hogan, Robert E. (2001) 'The Influence of State and District Conditions on the Representation of Women in U.S. State Legislatures', American Politics Research 29(4): 4-24.

International Labor Organization (2008) LABORSTA. http://laborsta.ilo.org/STP/guest (February 10, 2011).

Inter-Parliamentary Union (2008) Women in Parliaments. http://www.ipu.org/wmne/world.htm (February 10, 2011). 
Jones, Mark P. (2009) 'Gender Quotas, Electoral Laws, and the Election of Women: Evidence from Latin American Vanguard', Comparative Political Studies 42(1): 56-81.

Kantola, Johanna (2009) 'Women's Political Representation in the European Union', The Journal of Legislative Studies 15(4): 379-400.

Katz, Richard S. (1980) A Theory of Parties and Electoral Systems, Baltimore, MD: John Hopkins University Press.

Kitschelt, Herbert (1994) The Transformation of European Social Democracy, New York, NY: Cambridge University Press.

Kittilson, Miki Caul (2006) Challenging Parties, Changing Parliaments. Women and Elected Office in Contemporary Western Europe, Columbus, OH: The Ohio State University Press.

Kotnarowski, Michal (2012) Personal communication (email). 2 April 2012.

Krook, Mona Lena (2009) Quotas for Women in Politics: Gender and Candidate Selection Reform Worldwide, New York: Oxford University Press.

Krook, Mona Lena (2010) 'Why Are Fewer Women than Men Elected? Gender and the Dynamics of Candidate Selection', Political Studies Review 8(2): 155-168.

Krook, Mona Lena and Pippa Norris (2014) 'Beyond Quotas: Strategies to Promote Gender Equality in Elected Office', Political Studies, doi: 10.1111/1467-9248.12116.

Long J. Scott (1997) Regression Models for Categorical and Limited Dependent Variables, vol. 7 of Advanced Quantitative Techniques in the Social Sciences, Thousand Oaks, CA: Sage.

Long J. Scott and Jeremy Freese (2006) Regression Models for Categorical Dependent variables Using Stata, Second Edition, College Station, TX: Stata Press.

Matland, Richard E. (2005) ‘Enhancing Women’s Political Participation: Legislative Recruitment and Electoral Systems', in A. Karam and J. Ballington (Eds.), Women in Parliament: Beyond Numbers. Stockholm, SE: IDEA. 
Matland, Richard E. and Donley T. Studlar (1998) 'Gender and the Electoral Opportunity Structure in the Canadian Provinces', Political Research Quarterly 51 (1): 117-140.

Matland, Richard E. and Donley T. Studlar (1996) 'The Contagion of Women Candidates in Single Member District and Proportional Representation Electoral Systems: Canada and Norway', The Journal of Politics 58(3): 707-733.

Murray, Rainbow, Mona L. Krook, and Opello, Katherine A. R. (2012) 'Why Are Gender Quotas Adopted? Party Pragmatism and Parity in France", Political Research Quarterly 65(3): 529-543.

Norris, Pippa (2006) 'Recruitment' in Katz, Richard S. and William J. Crotty (Eds.), Handbook of Party Politics, London: Sage.

Norris, Pippa (1996) 'Legislative Recruitment', in LeDuc, Lawrence, Richard G. Niemi, and Pippa Norris (Eds.), Comparing Democracies: Elections and Voting in Global Perspective. Thousand Oaks, California: Sage.

Norris, Pippa (1997) Passages to Power: Legislative Recruitment in Advanced Democracies, Cambridge: Cambridge University Press.

Norris, Pippa and Mark Franklin (1997) ‘Social Representation’, European Journal of Political Research 32 (2): 185-210.

Nieven, Daniel (1998) 'Party Elites and Women Candidates: The Shape of Bias', Women \& Politics, 19(2): 57-80.

OSCE (2009) 'Elections to the European Parliament, 4-7 June 2009. OSCE/ODIHR Exploratory Mission Report', available at: http://www.osce.org/odihr/elections/eu/36917. Last accessed: 13 July 2012.

Paxton, Pamela and Sheri Kunovich (2003) 'Women's Political Representation: The Importance of Ideology', Social Forces 82(1): 87-113.

Platenga, J., Chantal, R., Figueiredo, H., and Smith, M. (2009) 'Towards a European Union Gender Equality Index', Journal of European Social Policy 19(1): 19-33. 
Quota Project (2010) 'Global Database of Quotas for Women', available at:

http://www.quotaproject.org/. Last accessed: 1 July 2012.

Rahat, Gideon and Reuven Y. Hazan (2001) 'Candidate Selection Methods: An Analytical Framework' Party Politics 7(3): 297-322.

Reif, Karlheinz and Hermann Schmitt (1980) 'Nine Second-Order National Elections: A Conceptual Framework for the Analysis of European Election Results', European Journal of Political Research 8(1): 3-44.

Renwick, Alan and Jean-Benoit Pilet (2011) 'The Personalization of Electoral Systems: Theory and European Evidence', paper presented at the General Conference of the European Consortium for Political Research, Reykjavik, Iceland.

Reynolds, Andrew (1999) 'Women in the Legislature and Executives of the World: Knocking the Highest Glass Ceiling', World Politics 51(4): 547-572.

Ryan, Michelle K., S. Alexander Haslam, and Clara Kulich (2010) 'Politics and the Glass Cliff: Evidence that Women are Preferentially Selected to Contest Hard-to-Win Seats', Psychology of Women Quarterly 34(1): 56-64.

Sanbonmatsu, Kira (2002) 'Gender Stereotypes and Vote Choice', American Journal of Political Science 46(1): 20-34.

Scarrow, Susan E. (1997) 'Political Career Paths and the European Parliament', Legislative Studies Quarterly 22(2): 253-263.

Schwindt-Bayer, Leslie A. and William Mishler (2005) ‘An Integrated Model of Women’s Representation', The Journal of Politics 67(2): 407-428.

Shugart, Matthew S., Melody E. Valdini, and Kati Suominen (2005) 'Looking for Locals: Voter Information Demands and Personal Vote-Earning Attributes of Legislators under Proportional Representation', American Journal of Political Science 49(2): 437-449.

Smith, Eric R.A.N. and Richard L. Fox (2001) 'The electoral fortunes of women candidates for Congress', Political Research Quarterly 54(1): 205-221. 
Tripp, Aili M. and Alice Kang (2008) 'The Global Impact of Quotas: On the Fast Track to Increased Female Legislative Representation', Comparative Political Studies 41(3): 338361.

Valdini, Melody E. (2012) 'A Deterrent to Diversity: The Conditional Effect of Electoral Rules on the Nomination of Women Candidates', Electoral Studies, doi: 10.1016/j.electstud.2012.06.011. 


\section{TABLES}

Table 1: Explaining candidates' likelihood of party determined viable candidacy, multinominal logistic regression estimates

\begin{tabular}{|c|c|c|c|c|c|}
\hline & $\begin{array}{l}\text { Doubtful / } \\
\text { Unpromising }\end{array}$ & & \multicolumn{2}{|c|}{ Safe / Unpromising } & Safe / Doubtful \\
\hline Female & $-0.00(0.32)$ & & $0.63(0.47)$ & & $0.63(0.58)$ \\
\hline Political experience & $1.39(0.46)$ & $* *$ & $1.40(1.17)$ & & $0.01(0.98)$ \\
\hline Political ambition: MEP & $-0.29(0.31)$ & & $-1.32(0.67)$ & + & $-1.02(0.69)$ \\
\hline Preference voting: ordered list & $-0.13(0.46)$ & & $-0.22(0.70)$ & & $-0.09(0.90)$ \\
\hline Gender equality & $-0.43(1.95)$ & & $1.72(4.35)$ & & $2.15(4.32)$ \\
\hline Simple quotas & $0.83(0.56)$ & & $0.46(1.10)$ & & $-0.38(0.96)$ \\
\hline Quotas with placement mandate & $0.76(0.54)$ & & $1.69(0.70)$ & ** & $0.93(1.10)$ \\
\hline Left/liberal/green party & $0.03(0.35)$ & & $0.76(0.84)$ & & $0.73(0.68)$ \\
\hline District magnitude & $0.00(0.01)$ & & $0.01(0.01)$ & & $0.01(0.02)$ \\
\hline Centralised candidate selection & $0.36(0.25)$ & & $1.28(0.82)$ & & $0.92(0.67)$ \\
\hline Inclusive selectorate & $0.28(0.19)$ & & $-0.10(0.23)$ & & $-0.38(0.28)$ \\
\hline Constant & $-3.79(1.52)$ & * & $-7.47(4.01)$ & + & $-3.68(3.19)$ \\
\hline $\mathrm{N}$ & 1020 & & & & \\
\hline Level $2 \mathrm{~N}$ & 20 & & & & \\
\hline LR Chi2 (20) & 253.54 & ** & & & \\
\hline Log likelihood & -670.311 & & & & \\
\hline Pseudo R2 & 0.159 & & & & \\
\hline
\end{tabular}

Source: 2009 EES Candidate Survey Data

${ }^{*} \mathrm{p}<0.01 ;{ }^{*} \mathrm{p}<0.05 ;+\mathrm{p}<0.10$ (two-tailed tests); robust standard errors (clustered by country) in parentheses. 
Table 2: Explaining female and male candidates' likelihood of party determined viable candidacy, multinominal logistic regression estimates

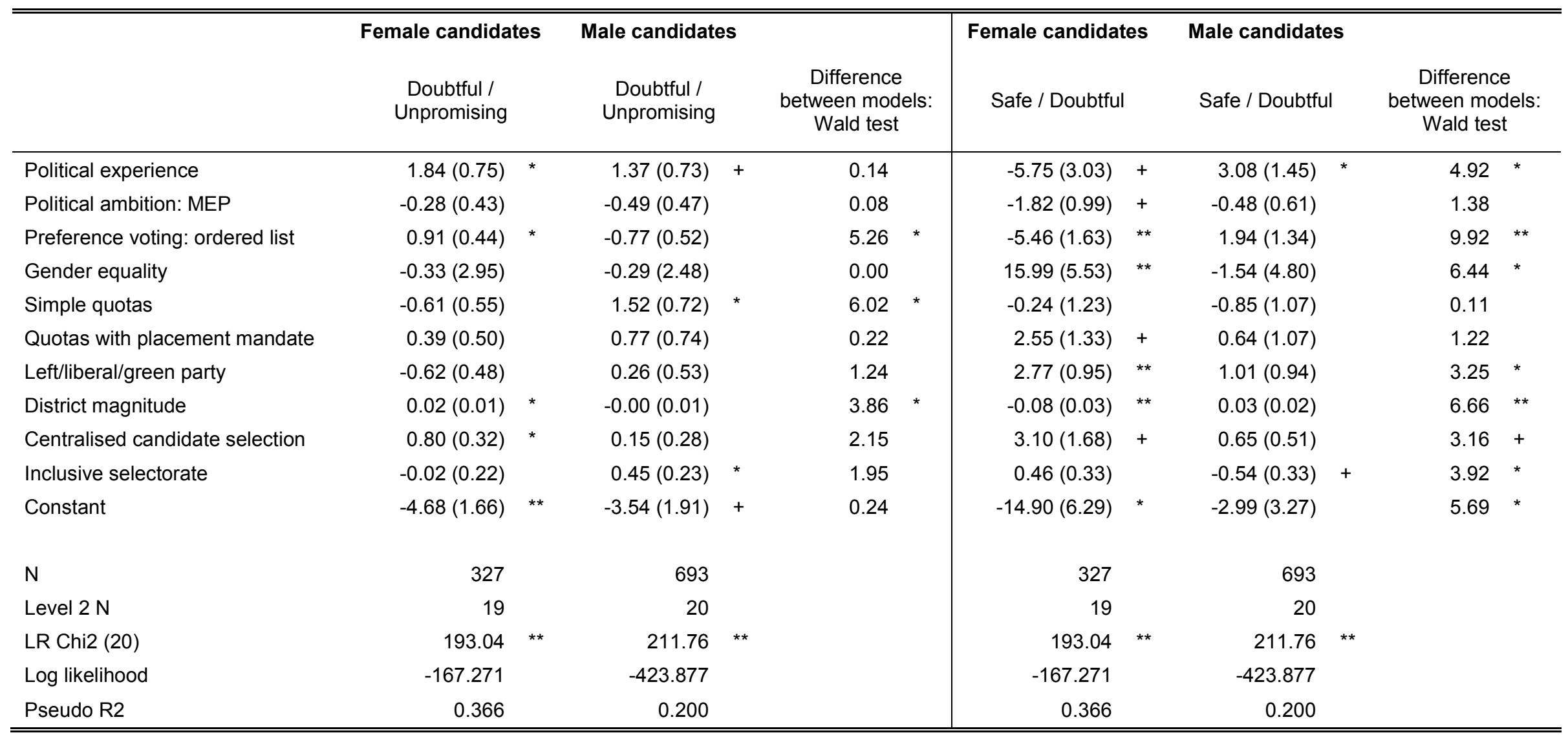

Source: 2009 EES Candidate Survey Data

${ }^{* *} \mathrm{p}<0.01 ;{ }^{*} \mathrm{p}<0.05 ;+\mathrm{p}<0.10$ (two-tailed tests); robust standard errors (clustered by country) in parentheses. 


\section{FIGURES}

Figure 1: Predicted probabilities of party-determined candidate viability for women by voting system, gender equality, and candidate selection level

Candidate viability by voting system and gender equality
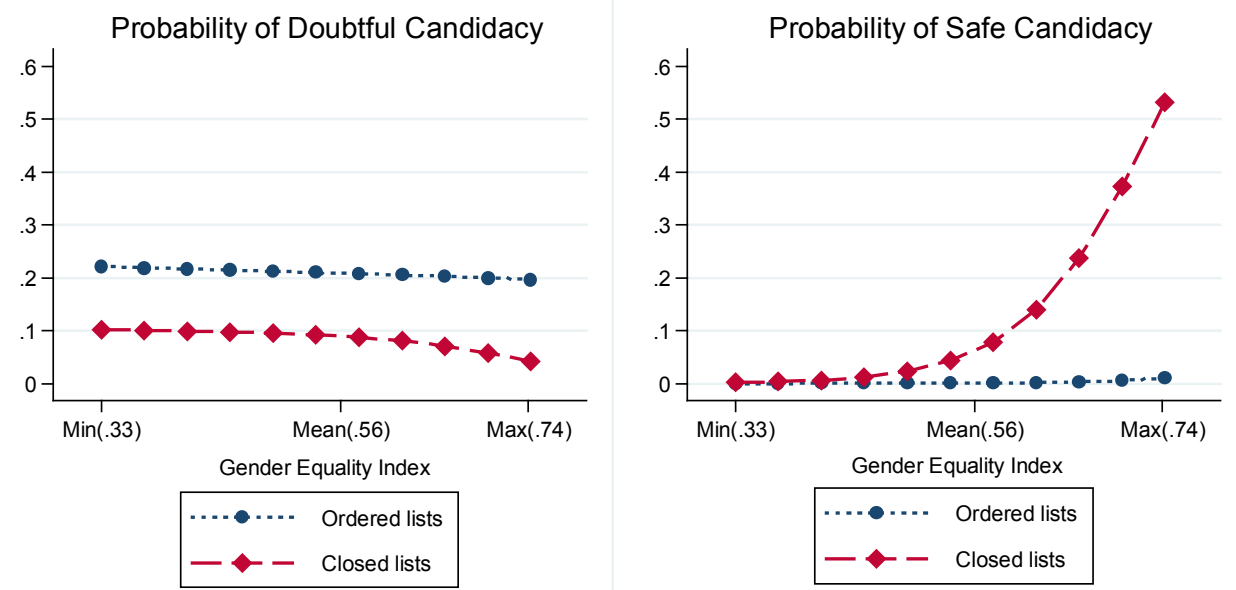

Candidate viability by voting system and selection level
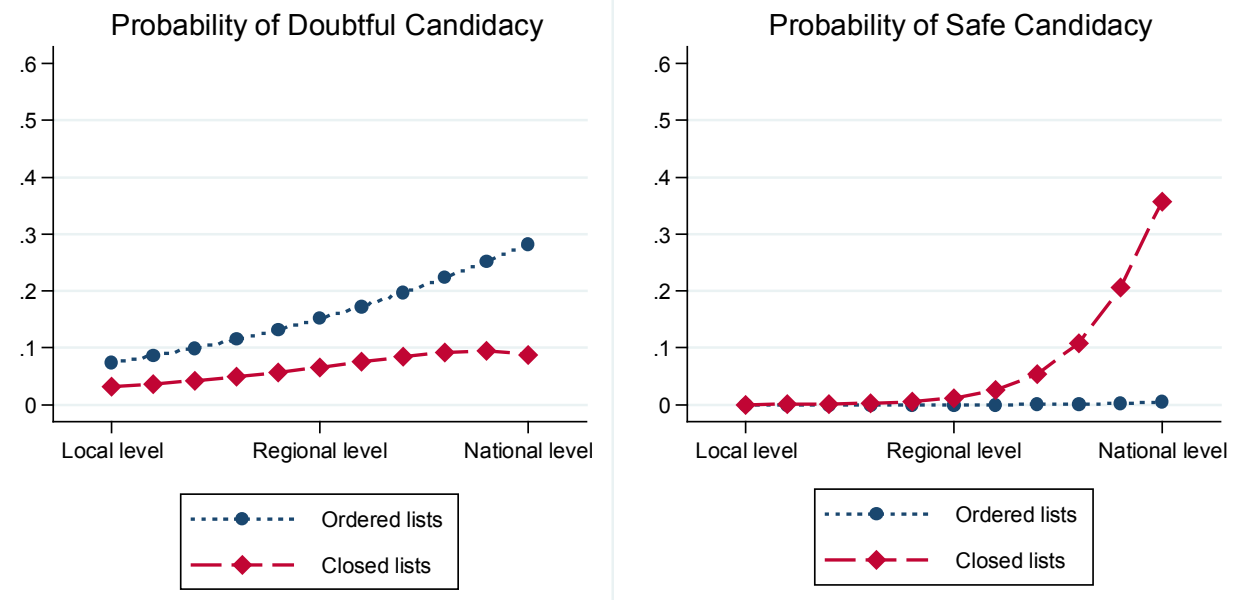

Note: Predicted probabilities obtained from female candidate model estimates in Table 2. All other covariates are set at estimation sample mean. 
Figure 2: Predicted probabilities of party-determined candidate viability for women by gender equality, candidate selection level, and party ideology

Candidate viability by gender equality and selection level
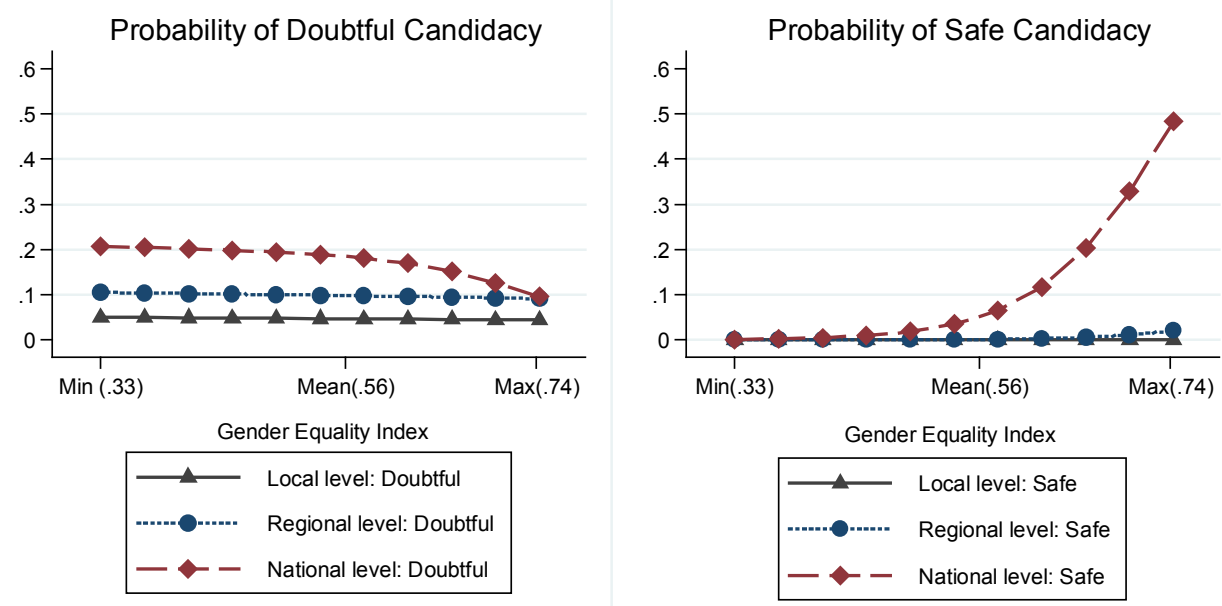

Candidate viability by gender equality and party ideology
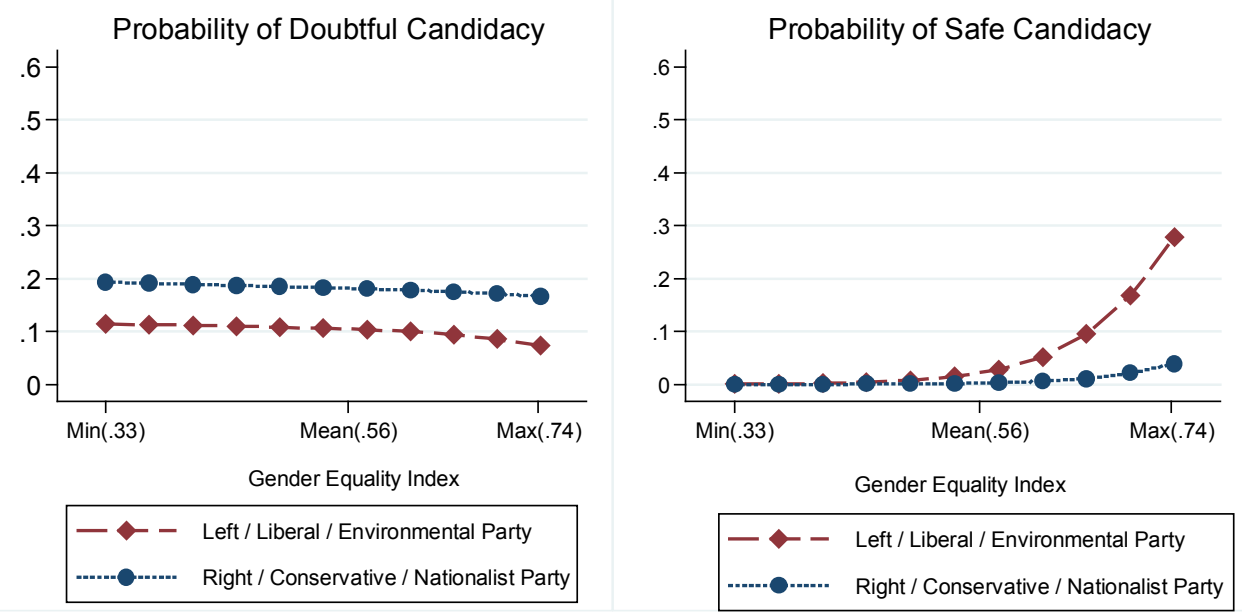

Note: Predicted probabilities obtained from female candidate model estimates in Table 2. All other covariates are set at estimation sample mean. 


\section{Appendix 1: Measurement of overall gender equality}

I use the following eight indicators to measure the different dimensions of gender equality:

- Equal share of employment: (1) gender gap in employment; (2) gender gap in unemployment.

- Equal share of money: (3) gender pay gap; (4) gender gap in risk of poverty after social transfer.

- Equal share of power: (5) gender gap in national parliament (lower chamber); (6) gender gap in ISCO 1 level occupations.

- Equal share of time: (7) gender gap in hours spent educating children and caring for them among people in full-time employment; (8) gender gap in hours spent cooking and doing house chores among people in full-time employment.

Since the indicators are measured on different scales, the actual values of the indicators are standardised using the min-max methodology in order to calculate the composite index. The formula is:

Standardised value $=\frac{\mid \text { actual value } \mathrm{x} 1 \mid- \text { min value } \mathrm{x} 1}{\max \text { value } \mathrm{x} 1-\min \text { value } \mathrm{x} 1}$ where the actual value is a national score on the indicator (i.e., gender gap of $5 \%$ in unemployment); where a situation of absolute equality (no gender gap) refers to the maximum value and has assigned the value 0 ; and where the minimum value is set at a level which is a little below the actual minimum value within the sample of EU countries. Since gender equality is understood as the absence of gender gaps, both positive and negative gaps are treated the same way which means that the absolute value of the gender gap is used. As a result, the standardised values of each indicator vary between 0 and 1 , where 0 corresponds to a situation of the worst inequality in the $\mathrm{EU}$, and 1 corresponds to a situation of absolute equality. Table A summarises the scores of overall gender equality across EU member states. 
Table A: Overall ranking of $27 \mathrm{EU}$ member states on gender equality index (2007-2009)

\begin{tabular}{|c|c|c|c|c|c|c|c|c|c|}
\hline Country & Employment & Unemployment & Pay & Risk of poverty & Political power & $\begin{array}{r}\text { Socio- } \\
\text { economic } \\
\text { power }\end{array}$ & Care activities & $\begin{array}{r}\text { Household } \\
\text { activities }\end{array}$ & $\begin{array}{r}\text { Composite } \\
\text { index score }\end{array}$ \\
\hline Sweden & 0.88 & 0.91 & 0.42 & 0.98 & 0.93 & 0.49 & 0.74 & 0.58 & 0.74 \\
\hline Finland & 0.95 & 0.81 & 0.35 & 0.69 & 0.8 & 0.41 & 0.93 & 0.67 & 0.7 \\
\hline Denmark & 0.85 & 0.84 & 0.43 & 0.87 & 0.72 & 0.25 & 0.85 & 0.67 & 0.68 \\
\hline Belgium & 0.67 & 0.96 & 0.71 & 0.72 & 0.65 & 0.51 & 0.7 & 0.33 & 0.66 \\
\hline France & 0.75 & 0.91 & 0.45 & 0.89 & 0.25 & 0.67 & 0.56 & 0.5 & 0.62 \\
\hline Poland & 0.61 & 0.87 & 0.76 & 0.91 & 0.3 & 0.61 & 0.48 & 0.42 & 0.62 \\
\hline Bulgaria & 0.75 & 0.94 & 0.6 & 0.62 & 0.33 & 0.49 & 0.74 & 0.42 & 0.61 \\
\hline Hungary & 0.67 & 0.91 & 0.47 & 1 & 0.08 & 0.61 & 0.78 & 0.33 & 0.61 \\
\hline Romania & 0.61 & 0.73 & 0.59 & 0.82 & 0.09 & 0.41 & 0.78 & 0.83 & 0.61 \\
\hline Slovenia & 0.79 & 0.99 & 0.73 & 0.47 & 0.14 & 0.58 & 0.74 & 0.42 & 0.61 \\
\hline Portugal & 0.72 & 0.81 & 0.73 & 0.67 & 0.49 & 0.46 & 0.74 & 0.17 & 0.6 \\
\hline Luxembourg & 0.52 & 0.8 & 0.6 & 0.78 & 0.37 & n.d. & 0.56 & 0.42 & 0.58 \\
\hline Spain & 0.59 & 0.9 & 0.45 & 0.56 & 0.68 & 0.49 & 0.56 & 0.25 & 0.56 \\
\hline Latvia & 0.99 & 0.08 & 0.5 & 0.38 & 0.29 & 0.75 & 0.78 & 0.58 & 0.55 \\
\hline Germany & 0.72 & 0.84 & 0.26 & 0.6 & 0.58 & 0.65 & 0.41 & 0.25 & 0.54 \\
\hline Netherlands & 0.68 & 0.99 & 0.24 & 0.8 & 0.8 & 0.36 & 0.04 & 0.42 & 0.54 \\
\hline Italy & 0.35 & 0.64 & 0.84 & 0.47 & 0.32 & 0.52 & 0.81 & 0.17 & 0.52 \\
\hline Slovakia & 0.56 & 0.8 & 0.24 & 0.75 & 0.28 & 0.42 & 0.59 & 0.33 & 0.5 \\
\hline UK & 0.71 & 0.69 & 0.32 & 0.58 & 0.28 & 0.56 & 0.41 & 0.42 & 0.5 \\
\hline Austria & 0.69 & 0.94 & 0.18 & 0.51 & 0.47 & 0.38 & 0.33 & 0.17 & 0.46 \\
\hline Lithuania & 0.96 & 0.04 & 0.35 & 0.18 & 0.24 & 0.72 & 0.59 & 0.5 & 0.45 \\
\hline Czech Rep. & 0.5 & 0.74 & 0.24 & 0.67 & 0.19 & 0.37 & 0.33 & 0.42 & 0.43 \\
\hline Ireland & 0.74 & 0.01 & 0.45 & 0.55 & 0.14 & 0.48 & 0.56 & 0.42 & 0.42 \\
\hline Malta & 0.01 & 0.86 & 0.75 & 0.8 & 0.03 & 0.07 & 0.59 & 0.17 & 0.41 \\
\hline Estonia & 0.97 & 0.1 & 0 & 0.09 & 0.31 & 0.61 & 0.22 & 0.67 & 0.37 \\
\hline Cyprus & 0.56 & 0.96 & 0.25 & 0.29 & 0.16 & 0.03 & 0.63 & 0.08 & 0.37 \\
\hline Greece & 0.28 & 0.1 & 0.31 & 0.76 & 0.17 & 0.38 & 0.59 & 0.08 & 0.33 \\
\hline
\end{tabular}

Sources: European Foundation for the Improvement of Living and Working Conditions 2009; Eurostat 2009; Eurostat 2007a; Eurostat 2007b; International Labor Organisation 2008; Inter-Parliamentary Union 2008. 
